\title{
The beauty of continuous development of the nurse as the beauty of nursing as an art
}

\author{
Piękno ciągłego rozwoju pielęgniarki pięknem pielęgniarstwa jako sztuki
}

\section{Zygmunt Pucko', Joanna Przybek-Mita²}

\author{
'Wydział Nauk o Zdrowiu, Uniwersytet Jagielloński Collegium Medicum/ \\ Faculty of Health Sciences, Jagiellonian University Medical College \\ ${ }^{2}$ Wydział Medyczny, Uniwersytet Rzeszowski/Medical College of University of Rzeszów \\ CORRESPONDING AUTHOR/AUTOR DO KORESPONDENCJI: \\ Zygmunt Pucko \\ Wydział Nauk o Zdrowiu, Uniwersytet Jagielloński Collegium Medicum \\ ul. Armii Krajowej 89/61, 30-150 Kraków \\ e-mail: zygmunt.pucko@uj.edu.pl
}

STRESZCZENIE

Słowa kluczowe:

ABSTRACT

Key words:

\section{PIEKNO CIAGKEGO ROZWOJU PIELEGNIARKI PIEKNEM PIELEGNIARSTWA JAKO SZTUK}

Wprowadzenie. Spoglądając z perspektywy filozoficznej na ustawiczny proces kształcenia się pielęgniarki można w nim dostrzec taki wymiar, który do tej pory nie został wydobyty na światło dzienne. Tymczasem dodaje on pielęgniarce większego splendoru oraz szacunku. Zmienia również postrzeganie pielęgniarki w świadomości zbiorowej i kreuje jej nowe wyobrażenie w kodzie kulturowym. Tym aspektem jest piękno, które określa również pielęgniarstwo rozumiane jako sztuka. Ramę teoretyczną rozważań stanowi koncepcja estetyki Cypriana Kamila Norwida. Jego ujęcie przesądza o estetycznym odcieniu ciągłego rozwoju pielęgniarki i legitymizuje estetyczny status takich kategorii myślowych jak np. dynamizm, celowość, współmierność, głębia, oryginalność, dopełnienie, rygor czy ascetyzm. Upoważnia też do utożsamienia pielęgniarstwa ze sztuką i uchyla drzwi dla współczesnych wytłumaczeń takiej identyfikacji. Cel pracy. Ukazanie piękna ustawicznego rozwoju pielęgniarki. Wskazanie cech konstytutywnych piękna ciągłego kształcenia się. Próba uzasadnienia nadania pielęgniarstwu miana sztuki.

Metoda. Metoda fenomenologiczna. Metoda ta opracowana została przez Edmunda Husserla i sprowadza się do oglądu oraz opisu fenomenu lub rzeczy, które są dane badaczowi naocznie. Celem tej metody jest dotarcie do istoty ujmowanego poznawczo przedmiotu i jej rozpoznanie w sposób jasny i wyraźny. Uchwycenie kwintesencji jakiegoś fenomenu czy rzeczy dokonuje się poprzez redukcję fenomenologiczną oznaczająca bezzałożeniowość w podejściu badawczym i tak zwany ogląd ejdetyczny.

Wnioski. Trwałe kontinuum procesu doskonalenia się pielęgniarki ma walor estetyczny. Pielęgniarstwo od kilku dekad zostało podniesione do rangi sztuki. Wprowadzenie pielęgniarstwa do panteonu sztuki jest dowodzone z różnych punktów widzenia. Pielęgniarstwo pojmowane jako sztuka nie dysponuje jeszcze spójną teorią ani precyzyjną siatką pojęciową. Na podstawie wypadkowej wielu argumentów tę nobilitację pielęgniarstwa trudno podważyć.

piękno, rozwój, sztuka, pielęgniarka, pielęgniarstwo

Introduction. Looking from a philosophical perspective at the continuous process of the nurse's education, one can see in it a dimension that has not yet been brought to light. Meanwhile, it gives the nurse greater splendour and respect. It also changes the perception of the nurse in collective consciousness and creates her new image in the cultural code. This aspect is beauty, which also defines nursing understood as an art. The theoretical frame of this consideration is the concept of aesthetics of Cyprian Kamil Norwid. His approach determines the aesthetic shade of the nurse's continuous development and legitimizes the aesthetic status of such thought categories as e.g. dynamism, purposefulness, proportionality, depth, originality, complementation, rigor or asceticism. It also authorizes the identification of nursing with art and opens the door for contemporary explanations of such identification.

Aim. To show the beauty of the continuous development of the nurse. Indication of the constitutive features of the beauty of continuous learning. An attempt to justify giving nursing the title of an art.

Method. Phenomenological method. This method was developed by Edmund Husserl and consists in viewing and describing a phenomenon or an object given to the researcher by eye. The purpose of this method is to get to the essence of the cognitively understood object and to recognize it clearly and distinctly. Capturing the quintessence of a phenomenon or an object is achieved through phenomenological reduction, meaning presuppositionlessness in the research approach and the so-called eidetic view.

Conclusions. The permanent continuum of the nurse's development process has an aesthetic value. Nursing has been elevated to the rank of art for several decades. The introduction of nursing to the pantheon of an art is proved from various points of view. Nursing understood as an art does not yet have a consistent theory or precise conceptual grid. Based on the resultant of many arguments, this ennoblement of nursing is difficult to challenge.

beauty, development, art, nurse, nursing 


\section{INTRODUCTION}

Because a lamp cannot remain under a bushel basket,

Nor the salt of the earth among the kitchen spices,

The purpose of beauty is to enchant. (...)

Beauty is the shape of love [1].

This motto comes from the poetic treatise Promethidion by Cyprian Kamil Norwid. This late romantic explains in it the meaning of the existence of beauty and explains its essence with a metaphor of shape. According to our pen coryphaeus, the essence of beauty lies in the connection between internal content and its embodiment in external form [2]. According to Norwid, this coherence is steeped in some celestial element and never loses it. The earthly particle is a trace permanently imprinted in it. Therefore, in many stanzas of the quoted text, the poet calls beauty a "profile of divinity”, which is manifested in almost everything. Conceived in this way, the metaphor of shape is the key to understanding Norwid's innovative concept of aesthetics.

His beauty is not limited to works of art or their forms such as speech, language, poetry, drama, singing or music. Nor does Norwid associate beauty only with sensory impressions, which are accompanied by a wide range of various physiological conditions, e.g. muscle tremor, high blood pressure, goose bumps or tears, and psychological moods such as anxiety, sadness, regret or joy, ecstasy, internal agitation, a sense of harmony or even being transported beyond time and space.

Based on the linguistic analysis of Norwid's texts, it appears that he also included in the universe of beauty a rich spectrum of cognitive, moral, sacral, utilitarian and hedonistic values. In Norwid's vision of aesthetics, beauty is intertwined with decency, human work, suffering and care [3]. The adjective „beautiful” was also applied by the poet to such nouns as: man, life, world, deeds, needs, thought, and law. He named beauty with everything that aroused his admiration, respect and pleasure [4]. In his philosophy of beauty, he highly valued creative attitude. The poet's attitude to the role of the human agere is reflected in frequent references to two „creative” Greek myths. One is the story of Pygmalion. The second one is the story of Promethidion. With each reference to these works, Norwid brought to the fore the creative power of man [4]. It is easy to notice that Norwid gave beauty a new character that sparkled with previously unknown colours [2]. His intellectual feat confirmed the view that the concept of beauty remains open to various interpretations and regardless of the appearance it takes, is always uniquely attractive.

\section{AIM}

This article has three important objectives. First, to show the beauty of the continuous development of the nurse. Secondly, to indicate the constitutive features of the beauty of continuous learning. Thirdly, it is an attempt to justify giving nursing the title of an art.

\section{METHOD}

The phenomenological method. The phenomenological method derives its name from the Greek phainomenon, denoting phenomenon. In the word phainomenon there is a core phos, meaning light. Thanks to this light, each phenomenon reveals itself, i.e. it presents itself to the researcher and allows the researcher to get to know itself in this self-presentation. The starting point of the phenomenological method is "seeing." According to Edmund Husserl, the author of this method, "seeing” is also associated with a conscious experience in which the researcher encounters a given object that appears to them „in itself” as something that is currently present to them. Perceived in this way, „seeing” is regarded as the actual source of the certainty sought by the researcher, because then there is no discrepancy between their thought and what appears to them. The researcher thinks as much, and only as much, as they can see; and what they see, they see with all clarity and distinctiveness [5]. The fundamental components of this method are careful observation and reliable description of what is given visually and how it is given. The phenomenological method in the view of Edmund Husserl and his followers postulates the presuppositionlessness and impartiality of the researcher's attitude towards the observed object.

Presuppositionlessness, defined in philosophical language as phenomenological reduction, consists in bracketing the existing knowledge, beliefs, speculations, and guesses held by the person who possesses knowledge about a particular object in order to clear the mind. Releasing the mind of all this is also a form of preparing it to grasp the essence of the phenomenon in an eidetic view. The researcher, by maintaining such an attitude, „clings to” the object they describe and presents it as it really is in its communication with all obviousness of the meaning that it has originally and objectively [5].

\section{Main body}

The multi-faceted beauty in the poet-artist's work is a great incentive to consider in its horizon the issue of continuous development of the nurse. A source view of this subtle matter allows us to see in it a number of aesthetic categories par excellence. Immediately, almost with a peremptory obviousness, „dynamism” of development emerges. It is known that resilience has long been considered a variety of beauty and is nowadays often treated as its attribute [6].

The enterprising drive of the nurse's development is manifested by an unharnessed rush towards eternal high rise. The course of her growth will not be satisfied by any transformation that does not raise the bar upwards because ideas change, absolute value systems perish, knowledge evolves, technology transforms, people's mentality undergoes metamorphosis, the environment transfigures. Everything exists in unique time and place reference systems. Vitality of continuous development verifies the importance of existing knowledge and eliminates its deficiencies. On the way to expanding the repertoire of possibilities, the nurse changes herself, i.e. who she was. 
She modifies what she knew and did. The resilience of the continuous development of the nurse raises her competences to the optimum, unattainable for her in any other way.

The property that specifies the beauty of continuous development is "purposefulness”, as the multiplication of one's own potential takes place in the training chain, and not in separate episodes unrelated to each other by any unifying idea. All links in the education form a coherent whole and harmoniously combine in such a way that short-term goals constitute means to gain further goals. Purposefulness reveals a strong sense of professional identity, a conscious vision of oneself and a high degree of approval of one's actions taken in the name of one's own and the common good.

Another distinguishing feature constituting the beauty of the nurse's development is „suitability”. It manifests itself in tuning the acquired content with the ability to use the right methods to best deal with the challenges posed by nursing in the present and in the near future. Proportionality is also an adequate response to a combination of various issues emerging in everyday practice. The consequence of this symmetry may be, for example, personalized care. Adaptability guarantees a quicker and easier decision for the nurse regarding the patient and enables focusing energy on providing effective care.

The consistency of beauty of development is modelled by the "depth" of internal integration of the growing scale of thought and emotional sensitivity. In the continuum of development, „originality” has an aesthetic value. It is a manifestation of criticism and distance from existing patterns. It is the fruit of seeking avant-garde solutions and creating standards other than those that have existed so far. After all, efforts focused on ornamenting developmental physiognomy cannot be routine. Innovation improves one's own knowledge and rebuilds technique. It focuses on exploring areas not yet explored and confronting one's own achievements with the achievements of other scientific disciplines. Ingenuity, however, does not mean going beyond the axiological horizon. Although it does shatter old tablets, it maintains the bipolar ethics of good and evil, and the bivalent logic of truth and falsehood.

The course of development to the heights of beauty is carried by „complement”. However you understand it, it will always be associated with the term fullness, whose semantic scope is the opposite of any shortcomings. After all, the word „complement” speaks of something that had been becoming and required to be completed prior to its completion. Therefore, it concerns a process or something that is subject to this process. In some currents of aesthetics deriving its genealogy from the noble tradition sanctioned by the authority of Thomas Aquinas, it is believed that fullness is one of the most important factors of beauty [2].

The list of aesthetic imponderables of the nurse's continuous development should include „a multitude of issues”, „tension” and „rigor”. These terms can be found in the extensive list of beauty varieties compiled by Roman Ingarden [7].
"Asceticism” is a particularly important category that combines the pragmatism of development with beauty. However, asceticism in this analysis does not speak of mortifying the body or tormenting the spirit with penitential practices as in classical Christian spirituality, but has positive associations. The Greek verb askein was defined by their prism [8]. It communicates, among other things, the elaborate processing, decorating, dressing, practicing some art, and training of intellect and mental abilities. The noun askesis comes from the verb related to the style of performing a profession or following an occupation [9]. Its synonymous counterpart is the noun asketes reserved to a person expert and competent in some field, who must be considered a master in producing beautiful, noble and good works. In contrast, the adjective asketos [9] points to an intricately, even artistically trained skill or a sublime way of being in the world in terms of culture.

Friedrich Nietzsche wrote about such persons that they themselves became the creators of their beauty and are their own masterpiece of a dignified soul expressed in a real excess of taste [10]. The taste contains, as Zbigniew Herbert suggests, all "fibres of the soul and cartilage of conscience" [11]. Naturally, this admirer of the power of taste does not exhaust its complexity. Nevertheless, based on the above data, one can suppose that Norwid would rather not mind if it was said as part of the summary of this part of the essay that the shape of the continuous development of the Polish nurse is beauty.

The space of exposure of the outlines of the beauty of the nurse's development is nursing defined as an art. The identification of nursing with art may seem a bit surprising, since medicine had the status of an art almost from the beginning of its birth. Nursing was considered a craft and was associated with craft [12]. This type of collective perception of nursing has its roots in the flesh of historical and cultural tissue itself and is clearly reflected in the linguistic plane.

For many decades, within the English language, nursing was named, contrary to Florence Nightingale's ambitions, by the term craft and reduced to the labour realm [13]. For the record, it seems worth signalling that the noun craft denotes a hand-made profession [14]. Labour, in turn, is an evocation of heavy drudgery, arduous work and even dirty work, which does not require considerable intellectual qualifications. Thanks to the achievements of a large group of eminent figures and the transformation of nursing, it has been raised to the rank of profession [14]. The correlate of the word profession is specialist knowledge requiring long and intensive academic preparation. From here, only a small step separated the profession of nursing from placing an equal sign between it and art.

The justification for ennoblement is provided by the analysis of the concepts of nursing and art compiled on the pages of numerous monographs and magazines. Reading them proves that this validation adopts various variants and is multidirectional. However, not all explanations are equally convincing. The logic of the argument suggests that it be limited to discussing a few selected positions with the greatest strength of argument. 
Following this train of thought, it is difficult to ignore the view that nursing is an art, because an art requires technical skills, dexterity and extensive knowledge. The ability to do something in nursing cannot do without human and specialist knowledge [15]. An art is mastering theoretical rules and applying them. Doing anything whatsoever and without following the rules, only under the influence of goodwill, compassion imperative or inspiration from the Muse is not an art. An art is a collection of common, apt, tested and useful standards that serve a specific purpose. According to Plato's views, one does "not call any irrational thing an art" [16].

The opinion that nursing belongs to art is determined in its theoretical reference system by the philosophical background. In the practical sphere, it determines the transformation of ideas into action. For this it is necessary to engage thought, work the imagination and use moral sensitivity. Just like in art. Without them, it is impossible to properly read the patient's most important needs, error-free selection of key values in the current situation [17], rapid assessment of medical parameters, personality and cultural indicators, skill in recognizing the uniqueness of each patient, tactful respect for the manifestations of his new feelings, finesse in manifesting understanding for the specifics of experiencing difficult situations [18].

The concept identifying nursing with art based on its feature, which is the expression of professional potential [19] and the ability to evoke specific experiences in patients [20], is resonant. It is within nursing that nurses through body language, verbal language, and style of performing specific activities demonstrate their culture of caring for others and, just like the artist, expresses their artistry in their own work. Through expression, the nurse stimulates the dynamics of the patient's internal experiences, sets thematic scope for reflection, stains his emotional tissue and ignites positive energy in him. The nurse's expression can be a kind of "voice" talking about the nuances of care and portraying the meaning of the symbolism of human experience [21]. All this is indisputably connected with the function of art and none of them can be denied.

Continuing to follow the path of legitimizing the aesthetic dimension of nursing is admittedly a cognitively interesting activity, but it is of little relevance to the main idea of this essay. It is time to move on to the discussion and formulate some general conclusions.

\section{DISCUSSION}

The reflections presented show that since the end of the last century, nursing has been claiming an honourable title of an art. In the light of these considerations, it is also known that individual authors prove the validity of this aspiration according to their own ideas. For this reason, the introduction of nursing to the pantheon of art is partly arbitrary. Inevitably, under the word ,art" only the name is common as in each individual case of its proving different reasons are given. However, no one can claim that art exists only if it has one consistent theory and boasts a precisely constructed conceptual grid.

We also deal with art when unusual things are created and realized. Witold Gombrowicz saw art, especially high art, wherever mediocrity and worship of superiority were denied [22]. For him, art was a matter of talent, prominence and strict hierarchy of values. In the eyes of the émigré writer, art seemed cruel to all common and bland things. Gombrowicz, particularly sensitive to beauty, thought that art is a matter of choosing and improving what is rare and irreplaceable. Finally, it is cultivating originality [22]. These components synchronize modern nursing like lens. Based on their focus, we dare to say that nursing is a sui generis elite art. Clasping the whole article with Norwid's intuition, it must be concluded that the shape of nursing as art is beauty.

\section{CONCLUSIONS}

The permanent continuum of the nurse's development process has an aesthetic value. Nursing has been elevated to the rank of art for several decades. The introduction of nursing to the pantheon of art is proved from various points of view. Nursing conceived as art, does not yet have a consistent theory or a precise conceptual grid. Based on the resultant of many arguments, this ennoblement of nursing is difficult to undermine.

\section{Piękno ciągłego rozwoju pielęgniarki pięknem pielęgniarstwa jako sztuki}

\section{WPROWADZENIE}

Bo nie jest światto, by pod korcem stało,

Ani sól ziemi do przypraw kuchennych,

Bo piękno na to jest, by zachwycało. (...) Ksztattem miłości piękno jest - $i$ tyle [1].

Przywołane motto pochodzi z poetyckiego traktatu Promethidion autorstwa Cypriana Kamila Norwida. Ów późny romantyk tłumaczy w nim sens istnienia piękna i metaforą kształtu wyjaśnia jego istotę. Według naszego koryfeusza pióra esencja piękna zawiera się w związku wewnętrznej treści $z$ jej ucieleśnieniem w zewnętrznej formie [2]. Zdaniem Norwida spójnia ta jest przesiąknięta wręcz jakimś niebiańskim pierwiastkiem i nigdy go nie traci. Zaziemska cząstka jest w niej śladem trwale odciśniętym. Dlatego $\mathrm{w}$ wielu strofach cytowanego utworu poeta nazywa piękno "profilem boskości”, który przejawia się nieomal we wszystkim. W ten sposób pojmowana przenośnia kształtu jest kluczem do zrozumienia nowatorskiej koncepcji estetyki Norwida. 
Obmyślone przez niego piękno nie ogranicza się do dzieł sztuki ani ich form takich jak: mowa, język, poezja, dramat, śpiew czy muzyka. Norwid nie łączy też piękna wyłącznie z wrażeniami zmysłowymi, którym towarzyszy bogata gama rozmaitych stanów fizjologicznych np. drżenie mięśni, podwyższone ciśnienie, gęsia skórka czy łzy i nastrojów psychicznych takich jak zaniepokojenie, smutek, żal albo radość, uniesienie, poruszenie wewnętrzne, poczucie harmonii lub nawet porwania poza czas i przestrzeń.

Na podstawie analizy językowej tekstów Norwida wynika, że do uniwersum piękna zaliczył on również bogate spektrum wartości poznawczych, moralnych, sakralnych, utylitarnych, hedonistycznych. W wizji estetyki Norwida piękno splata się z dobrymi obyczajami, ludzką pracą, cierpieniem, troską [3]. Przymiotnik „piękny” poeta stosował też do takich rzeczowników jak: człowiek, życie, świat, czyny, potrzeby, myśl, prawo. Pięknem mianował wszystko, co w jego przekonaniu budziło podziw, szacunek i upodobanie [4]. W swej filozofii piękna wysoko cenił postawę twórczą. Nastawienie poety do roli ludzkiego agere odzwierciedlają częste nawiązywania do dwóch „twórczych" mitów greckich. Jednym jest opowieść o Pigmalionie. Drugim dzieje Promethidiona. Za każdym odwołaniem się do tych utworów Norwid wydobywał na pierwszy plan kreacyjną moc człowieka [2]. Łatwo zauważyć, że Norwid nadał pięknu nową postać mieniącą się nieznanymi wcześniej kolorami. Swym intelektualnym wyczynem potwierdził pogląd, w myśl którego pojmowanie piękna pozostaje otwarte na różne interpretacje i niezależnie od wyglądu jaki przybierze zawsze jest niepowtarzalnie atrakcyjne.

\section{CEL}

Praca ma trzy ważne cele. Po pierwsze, ukazanie piękna ustawicznego rozwoju pielęgniarki. Po drugie, wskazanie cech konstytutywnych piękna ciągłego kształcenia się. Po trzecie, jest próbą uzasadnienia nadania pielęgniarstwu miana sztuki.

\section{METODA}

Metoda fenomenologiczna wywodzi swoją nazwę z greckiego słowa phainomenon oznaczającego zjawisko. $\mathrm{W}$ wyrazie phainomenon zawarty jest rdzeń phos, którym mianowano światło. Dzięki owemu światłu każde zjawisko odsłania siebie, czyli prezentuje się samo badaczowi i w tej autoprezentacji pozwala siebie poznać. Punktem wyjścia metody fenomenologicznej jest „widzenie”. U Edmunda Husserla będącego twórcą tej metody „widzenie” kojarzone jest również ze świadomym przeżyciem, w którym badacz obcuje z danym przedmiotem ukazującym się mu niejako „we własnej osobie” jako coś, co aktualnie jest dla niego obecne. W ten sposób pojęte „widzenie” uznaje się za faktyczne źródło poszukiwanej przez badacza pewności poznania, ponieważ wtedy nie ma żadnej rozbieżności między jego myślą a tym, co mu się jawi. Badacz myśli tyle i tylko tyle ile może zobaczyć, a to, co się mu jawi widzi z całą jasnością i wyrazistością [5].
Fundamentalnymi składnikami tej metody są uważny ogląd i rzetelny opis tego, co jest dane naocznie i w jaki sposób dane. Metoda fenomenologiczna w wydaniu Edmunda Husserla i jego kontynuatorów postuluje bezzałożeniowość oraz bezstronność w nastawieniu badacza do obserwowanej rzeczy. Bezzałożeniowość określana w języku filozoficznym redukcją fenomenologiczną polega na wzięciu w nawias dotychczasowej wiedzy, przekonań, spekulacji, domysłów żywionych przez podmiot poznający na temat jakiejś rzeczy w celu oczyszczenia umysłu. Uwalnianie umysłu z tego wszystkiego jest równocześnie formą przygotowania go do uchwycenia kwintesencji fenomenu w oglądzie ejdetycznym. Badacz utrzymując taką postawę „trzyma się" przedmiotu, który opisuje i przedstawia go takim jakim on naprawdę jest w swym udzielaniu się z całą oczywistością sensu jaki mu przysługuje pierwotnie i obiektywnie [5].

\section{OMÓWIENIE}

Wieloaspektowość piękna w wydaniu poety sztukmistrza stanowi znakomitą zachętę do rozważenia w jego horyzoncie kwestii ciągłego rozwoju pielęgniarki. Źródłowy ogląd tej subtelnej materii pozwala dostrzec w niej szereg kategorii estetycznych par excellence. Natychmiast, nieomal z apodyktyczną oczywistością narzuca się ,dynamizm" rozwoju. Wiadomo, że prężność od dawna uchodziła za odmianę piękna i w naszych czasach też jest nierzadko traktowana jako jego atrybut [6].

Żywość rozwoju pielęgniarki manifestuje się nieujarzmionym pędem ku wiecznej wspinaczce wzwyż. Toku jej wzrastania nie zadowoli żadna transformacja, która nie winduje poprzeczki w górę, ponieważ zmianie ulegają idee, murszeją bezwzględne systemy wartości, ewoluuje wiedza, przeobraża się technologia, metamorfozie ulega mentalność ludzi, przeistacza się środowisko. Wszystko istnieje w niepowtarzalnych układach odniesienia czasu i miejsca. Witalność nieustannego rozwoju weryfikuje wagę dotychczasowej wiedzy oraz likwiduje jej niedobory. W drodze wiodącej do poszerzenia repertuaru możliwości pielęgniarka zmienia siebie, czyli to kim była. Modyfikuje to, co wiedziała i czym się zajmowała. Sprężystość ciągłego rozwoju pielęgniarki podnosi jej kompetencje do optimum, nieosiągalne dla niej w żaden inny sposób.

Właściwością dookreślającą piękno ustawicznego rozwoju jest „celowość”, jako że zwielokrotnianie własnego potencjału dokonuje się w łańcuchu szkoleń, a nie w oddzielnych epizodach niepowiązanych ze sobą żadną jednoczącą je ideą. Wszystkie ogniwa kształcenia tworzą spójną całość i harmonijnie łączą się w taki sposób, że cele bliższe są środkami do zdobycia celów dalszych. Celowość unaocznia silne poczucie tożsamości zawodowej, świadomą wizję samej siebie oraz wysoki stopień aprobaty swoich działań podjętych w imię dobra własnego oraz wspólnego.

Kolejnym wyróżnikiem konstytuującym piękno rozwoju pielęgniarki jest „odpowiedniośc”. Manifestuje się ona zestrojeniem przyswajanych treści z umiejętnością zastosowania właściwych metod do najlepszego uporania się z wyzwaniami stawianymi pielęgniarstwu w teraźniej- 
szości i najbliższej przyszłości. Współmierność to także adekwatne zareagowanie na kombinację rozmaitych wątków ujawniających się w codziennej praktyce. Konsekwencją tej symetrii może być np. spersonalizowanie opieki. Przystawalność gwarantuje pielęgniarce szybsze i łatwiejsze podjęcie decyzji dotyczącej pacjenta i umożliwia skupienie energii na zapewnienia mu skutecznej opieki.

Konsystencję piękna rozwoju modeluje "głębia” wewnętrznej integracji powiększającej się skali myśli i emocjonalnej wrażliwości. W kontinuum rozwoju, estetycznym walorem legitymuje się „oryginalność”. Jest ona przejawem krytycyzmu i dystansu wobec zastanych wzorców. To wykwit poszukiwania awangardowych rozwiązań oraz tworzenia standardów innych niż te, które były do tej pory. Wszak starania skupione na ornamentowaniu fizjonomii rozwoju nie mogą być dziełem rutyny. Innowacyjność poprawia własną wiedzę i przebudowuje warsztat. Skupia się na eksplorowaniu obszarów jeszcze nie zbadanych i konfrontowaniu swoich osiągnięć z dorobkiem innych dyscyplin naukowych. Pomysłowość jednakże nie oznacza wyjścia poza aksjologiczny horyzont. Wprawdzie rozbija stare tablice, lecz zachowuje dwubiegunową etyką dobra i zła oraz dwuwartościową logiką prawdy i fałszu.

Tok rozwoju na wyżyny piękna dźwiga „dopełnienie”. Jakkolwiekby je rozumieć, zawsze będzie kojarzyć się z terminem pełnia, którego zakres semantyczny jest przeciwieństwem jakichkolwiek braków. Wszak wyraz „dopełnienie" mówi o czymś, co zanim doszło do kompletności najpierw stawało się i wymagało doprowadzenia do końca. Dotyczy zatem jakiegoś procesu albo czegoś, co temu procesowi podlega. W pewnych nurtach estetyki wywodzącej swą genealogię z nobliwej tradycji usankcjonowanej autorytetem Tomasza z Akwinu uważa się, że pełnia jest jednym z najważniejszych współczynników piękna [2].

$\mathrm{Na}$ listę estetycznych imponderabiliów permanentnego rozwoju pielęgniarki należy wciągnąć „mnogość zagadnień”, „napięcie” i „rygor”. Te terminy można znaleźć w obszernym wykazie odmian piękna sporządzonym przez Romana Ingardena [7].

Szczególnie doniosłą kategorią łączącą w sobie pragmatyzm rozwoju z pięknem jest „ascetyzm”. Przy czym, ascetyzm w snutych tu rozważaniach nie mówi o umartwieniu ciała czy zadręczaniu ducha pokutnymi praktykami tak jak w klasycznej duchowości chrześcijańskiej, lecz ma asocjacje pozytywne. Przez ich pryzmat definiowany był grecki czasownik askein [8]. Komunikuje on między innymi o kunsztownym obrabianiu, przyozdabianiu, przystrajaniu, uprawianiu jakiejś sztuki oraz trenowaniu intelektu i sprawności psychicznych. Od tegoż czasownika pochodzi rzeczownik askesis związany ze stylem spełniania profesji bądź wykonywania zawodu [9]. Jego bliskoznacznym odpowiednikiem jest rzeczownik asketes zastrzeżony do człowieka biegłego i kompetentnego w jakiejś dziedzinie, którego niepodobna nie uznać za mistrza w wytwarzaniu dzieł pięknych, szlachetnych i dobrych. Natomiast, przymiotnik asketos [9] wskazuje na misternie wręcz artystycznie wyćwiczoną umiejętność albo wysublimowany pod względem kultury sposób bycia w świecie.

O kimś takim Fryderyk Nietzsche pisał, że sam stał się twórcą swego piękna i jest własnym arcydziełem o duszy dostojnej wyrażającej się istnym zbytkiem smaku [10]. Smak zaś zawiera, jak sugeruje Zbigniew Herbert, wszystkie włókna duszy i chrzastki sumienia [11]. Naturalnie ów admirator potęgi smaku nie wyczerpuje jego złożoności. Niemniej w oparciu o powyższe dane wolno przypuszczać, że Norwid raczej nie miałby nic przeciwko, gdyby się powiedziało w ramach podsumowania tej części szkicu, że kształtem ciągłego rozwoju polskiej pielęgniarki piękno jest i tyle.

Przestrzenią ekspozycji zarysowanych konturów piękna rozwoju pielęgniarki jest pielęgniarstwo definiowane jako sztuka. Utożsamienie pielęgniarstwa ze sztuką może wydawać się nieco zaskakujące, ponieważ status sztuki przysługiwał medycynie nieomal od początku jej narodzin. Pielęgniarstwo zaś zaliczano do rzemiosła i z rzemiosłem kojarzono [12]. Ten rodzaj kolektywnego postrzegania pielęgniarstwa sięga korzeniami samego miąższu tkanki historyczno-kulturowej i wyraźnie odzwierciedla się w płaszczyźnie językowej. Przez długie dekady w obrębie języka angielskiego pielęgniarstwo mianowano, wbrew ambicjom Florence Nightingale, terminem craft i sprowadzano do rzędu labour [13]. Gwoli przypomnienia nie zaszkodzi zasygnalizować, że rzeczownik craft oznacza fach wykonywany ręcznie [14]. Labor z kolei jest ewokacją ciężkiej harówki, mozolnej pracy a nawet czarnej roboty, która nie wymaga dużych kwalifikacji intelektualnych. Dzięki osiągnięciom licznego grona wybitnych postaci i przeobrażeniom pielęgniarstwa podniesione ono zostało do rangi profesji [14]. Korelatem nazwy profession jest wiedza specjalistyczna oraz długie i intensywne przygotowanie akademickie. Stąd już tylko mały krok dzielił profesję pielęgniarstwa od postawienia znaku równości między nim a sztuką.

Uzasadnienia nobilitacji dostarcza analiza pojęć pielęgniarstwo-sztuka zestawionych na kartach licznych monografii i łamach czasopism. Ich lektura dowodzi, że uprawomocnienie to przyjmuje rozmaite warianty i jest wielokierunkowe. Nie wszystkie jednakże wytłumaczenia są w jednakowym stopniu przekonywujące. Logika wywodu podpowiada, aby w jego ramach ograniczyć się do omówienia kilku wybranych stanowisk o największej sile argumentacji.

Podążając tym tropem trudno pominąć pogląd, według którego pielęgniarstwo jest sztuką, ponieważ sztuka wymaga umiejętności technicznych, sprawności manualnej i szerokiej wiedzy. Zdolność wykonania czegoś w pielęgniarstwie nie może obyć się bez wiedzy o człowieku jak i wiedzy specjalistycznej [15]. Sztuka polega na opanowaniu reguł teoretycznych oraz ich stosowaniu. Robienie czegokolwiek i jakkolwiek bez przestrzegania prawideł, tylko pod wpływem dobrej woli, imperatywu współczucia lub z natchnienia Muz nie jest sztuką. Sztuka to zbiór powszechnych, trafnych, sprawdzonych oraz pożytecznych norm służących określonemu celowi. Zgodnie z zapatrywaniami Platona nie nazywa się sztuka irracjonalnej roboty [16].

Wiarygodna jest opinia zakładająca, że o przynależności pielęgniarstwa do sztuki decyduje w jego teoretycznym systemie odniesienia zaplecze filozoficzne. W sferze praktycznej zaś przesądza o tym przekucie idei w czyn. Do tego konieczne jest zaangażowanie myśli, praca wyobraźni oraz wykorzystywanie wrażliwości moralnej. Zupełnie tak jak w sztuce. Bez nich nie jest możliwe właściwe odczytywanie 
najważniejszych potrzeb pacjenta, bezbłędność wyboru kluczowych dla niego w aktualnej sytuacji wartości [17], błyskawiczne tempo oceny parametrów medycznych, wskaźników osobowościowych i kulturowych, wprawa w rozpoznawaniu niepowtarzalności każdego pacjenta, taktowne okazywanie szacunku wobec przejawów jego nowych odczuć, finezja w uzewnętrznianiu zrozumienia dla specyfiki przeżywania trudnych sytuacji [18].

Nośna jest koncepcja identyfikująca pielęgniarstwo ze sztuką na podstawie jej cechy, którą stanowi ekspresja potencjału zawodowego [19] i zdolność wywoływania u pacjentów określonych doznań [20]. To właśnie $\mathrm{w}$ łonie pielęgniarstwa pielęgniarka poprzez mowę ciała, język werbalny, styl wykonywania konkretnych czynności demonstruje swą kulturę troszczenia się o innych i podobnie jak artysta wyraża swój kunszt we własnym dziele. Za pośrednictwem ekspresji pielęgniarka pobudza dynamikę wewnętrznych przeżyć pacjenta, wytycza mu zakres tematyczny do przemyśleń, zabarwia jego emocjonalną tkankę oraz roznieca w nim pozytywną energię. Ekspresja pielęgniarki może być swego rodzaju „głosem” opowiadającym o niuansach troskliwości oraz portretowaniem znaczenia symboliki ludzkiego doświadczenia [21]. Wszystko to bezspornie łączy się z funkcją sztuki i żadnej z nich niepodobna zaprzeczyć.

Dalsze podążanie ścieżką legitymizacji estetycznego wymiaru pielęgniarstwa jest wprawdzie zajęciem ciekawym poznawczo, lecz mało przydatnym merytorycznie dla myśli przewodniej niniejszego eseju. Pora zatem przejść do dyskusji i sformułowania kilku wniosków natury ogólnej.

\section{DYSKUSJA}

Z zaprezentowanych refleksji wynika, że od końca minionego stulecia pielęgniarstwo rości sobie prawo do zaszczytnego tytułu sztuki. W świetle rozważań wiadomo również, że poszczególni autorzy dowodzą słuszności owej aspiracji według własnych wyobrażeń. Z tego powodu wprowadzenie pielęgniarstwa do panteonu sztuki jest po części arbitralne. Siłą rzeczy pod słowem „sztuka” kryje się wspólna tylko nazwa, ponieważ w każdym indywidualnym przypadku jej udowodnienia podaje się inne racje. Nikt jednakże nie może twierdzić, że sztuka istnieje tylko wtedy, gdy dysponuje jedną spójną teorią oraz szczyci się precyzyjnie zbudowaną siatką pojęciową.

Ze sztuką mamy do czynienia także wtedy gdy tworzy się i urzeczywistnia rzeczy niezwykłe. Sztukę, zwłaszcza wysoką Witold Gombrowicz, widział wszędzie, gdzie dochodziło do zaprzeczenia przeciętności i uwielbienia wyższości [22]. Sztuka była dla niego sprawą talentu, wybitności oraz surowym hierarchizowaniem wartości. W oczach emigracyjnego pisarza sztuka jawiła się okrucieństwem w stosunku do wszystkiego, co pospolite i nijakie. Gombrowicz szczególnie wyczulony na piękno sądził, że sztuka jest kwestią wyboru i doskonalenia tego, co rzadkie oraz niezastąpione. Jest wreszcie kultywowaniem oryginalności [22]. Te składowe synchronicznie skupia w sobie niczym soczewka współczesne pielęgniarstwo. Na podstawie ich zogniskowania śmiemy zaryzykować stwierdzenie, że pielęgniarstwo jest sui generis sztuką elitarną. Spinając całość artykułu Norwidowską intuicją niczym klamrą wypada skonstatować, że kształtem pielęgniarstwa jako sztuki piękno jest i tyle.

\section{WNIOSKI}

Trwałe kontinuum procesu doskonalenia się pielęgniarki ma walor estetyczny. Pielęgniarstwo od kilku dekad zostało podniesione do rangi sztuki. Wprowadzenie pielęgniarstwa do panteonu sztuki jest dowodzone z różnych punktów widzenia. Pielęgniarstwo pojmowane jako sztuka nie dysponuje jeszcze spójną teorią ani precyzyjną siatką pojęciową. Na podstawie wypadkowej wielu argumentów tę nobilitację pielęgniarstwa jednak trudno podważyć.

\section{REFERENCES/PIŚMIENNICTWO}

1. Norwid CK. Wybór poezji. Łódź: Wydawnictwo Łódzkie; 1988, s. 249.

2. Stróżewski W. Istnienie i wartość. Kraków: Wydawnictwo Znak; 1981, s. 194-195.

3. Gadamska-Serafin R. Promethidion Cypriana Norwida i List do artystów Jana Pawła II, czyli rozważania o pięknie prawdziwym. Tematy i Konteksty. 2012; 2 (7): 372-398.

4. Chojak J. red. Słownictwo estetyczne Cypriana Norwida. Warszawa: Uniwersytet Warszawski; 1994,s. 124.

5. Święcicka K. Husserl. Warszawa: Wiedza Powszechna; 1993, s. 40-43.

6. Tatarkiewicz W. Dzieje sześciu pojęć. Warszawa: PWN; 1988, s. 180.

7. Ingarden R. Przeżycie, dzieło, wartość, Kraków: Wydawnictwo Literackie; 1966, s. 163-194.

8. Abramowicz Z. Słownik polsko-grecki. Warszawa: PWN; 1958, s. 346.

9. Wójtowicz H. Asceza w hellenizmie. [w:] red. Słomka W, Asceza odczłowieczenie czy uczłowieczenie. Lublin: Towarzystwo Naukowe KUL; 1985, s. 60.

10. Nietzsche F. Dusza dostojna. Warszawa: Chimery; 1905, s. 30.

11. www.google.com/search?q=potęga+smaku+tekst\&oq=potęga+smaku\&aqs=ch rome, dostęp: 14 stycznia 2020.

12. Edwards SD. The Art of Nursing. Nursing Ethics. 1998; 5(5): 393-396.

13. Miller KL. A. Study of Nursing's Feminist Ideology. [w:] red. Neil RM, Wats R, Caring and Nursing: Explorations in Feminist Perspectives. New York: Center for Human Caring; 1991, s. 48.

14. Curtis S, Dawidson G. The New Penguin Compact English Dictionary. London: Penguin Books; 2010, s. 196.

15. Chinn PL. Toward a Theory of Nursing Art., [w:] red. Andrist LC, Nicholas PK. A History of Nursing Ideas. Boston: Jones and Bartlett Publishers; 2006, s. 175.

16. Platon, Gorgiasz. Sandomierz: Wydawnictwo Armoryka; 2017, s. 465.

17. Carper BA. Fundamental Patterns of Knowing in Nursing. Advances in Nursing Science. 1978; 1(1):13-23.

18. Alligood MR. A Theory of the Art of Nursing Discovered in Rogers' Science of Unitary Human Beings. International Journal for Human Caring. 2002; 6(2):55-60.

19. Alligood MR. The Theory of the Art of Nursing and the Practice of Human Care Quality. Visions. 2017;23(1):7.

20. Locsin RC. Art and Sciences in the Practice of Nursing. Songklanagarind Jouranal of Nursing. 2012; 32(1):41.

21. Johnson JL. A dialectical Examination of Nursing Art. Advances in Nursing Science. 1994; 17(1):1-14

22. Gombrowicz W. Dzienniki 1957-1961. Kraków: Wydawnictwo Literackie; 1988, s. 217.

Manuscript received/Praca zgłoszona do czasopisma: 31.10.2019

Manuscript accepted/Praca zaakceptowana do druku: 16.09.2020

Translation/Tłumaczenie: Marta Wójcik Czerwińska 